Bangladesh J. Zool. 49(1): 125-135, 2021

ISSN: 0304-9027

eISSN: $2408-8455$

\title{
TOXIC EFFECTS OF VITEX NEGUNDO L. AND POLYGONUM HYDROPIPER L. PLANT EXTRACT TREATED FISHES ON RATS
}

\author{
Molly Harun, Gulroo Begum Sufi and Gulshan Ara Latifa \\ Department of Zoology, University of Dhaka, Dhaka 1000, Bangladesh
}

\begin{abstract}
An observation was made to taste the toxic effect of Vitex negundo L. and Polygonum hydropiper L. (leaf and bark) plants extracts treated fish fed group on rats, Bandicota indica. Six group of rats were fed on two different kinds of plants extracts, one is radiation dose and another untreated control group. These were, the untreated control group rats were feed on normal food such as dried fish and wheat whereas treated rats were given plant extracts and radiation dose treated by dried fish. The experimental rats were fed of $4 \mathrm{ml}$ dose of plant extracts in $70 \%$ ethyl alcohol (ratio $1: 10$ ) and $4 \mathrm{kGy}$ radiation treated dry fish. The toxic properties of these plant extracts were carried out the vital organs of liver, kidney, stomach, spleens, lungs and muscles on male rats.The lower mammalian species rats were used for preliminary survey their body weight gained and histopathological changes were observed. The experiment was carried out from August 2004 to December 2004. Initially the concentration of rats body weights were found as, control group (C) $43 \mathrm{~g} / \mathrm{m}$, Vitex negundo leaf treated fish fed group of rat (VL) $44.8 \mathrm{~g} / \mathrm{m}$, Vitex negundo bark treated fish fed group of rat (VB) 44.4 $\mathrm{g} / \mathrm{m}$, Polygonum hydropiper leaf treated fish fed group of rat (PL) $46.2 \mathrm{~g} / \mathrm{m}$, Polygonum hydropiper bark treated fish fed group of rat (PB) $47.8 \mathrm{~g} / \mathrm{m}$ and radiation treated fish fed group of rat (R) $47 \mathrm{~g} / \mathrm{m}$. After 30 days the weight gain of rats recorded as, group (C) $324.6 \mathrm{~g} / \mathrm{m}$, (VL) $357.2 \mathrm{~g} / \mathrm{m}$, (VB) $362 \mathrm{~g} / \mathrm{m}$, (PL) 342 $\mathrm{g} / \mathrm{m}$, (PB) $323.6 \mathrm{~g} / \mathrm{m}$ and $(\mathrm{R}) 352 \mathrm{~g} / \mathrm{m}$ and 90 days after the body weight were group (C) $727.2 \mathrm{~g} / \mathrm{m}$, (VL) $781.2 \mathrm{~g} / \mathrm{m}$, (VB) $795.8 \mathrm{~g} / \mathrm{m}$, (PL) $780.4 \mathrm{~g} / \mathrm{m}$, (PB)764.8 $\mathrm{g} / \mathrm{m}$ and $\mathrm{R} 789.8 \mathrm{~g} / \mathrm{m}$ respectively. The present study is, the first attempt to use the rats body weight data found well and most suitable $4 \mathrm{ml}$ dose of $V$. negundo bark treated extracts than leaf treated group and 4 kGy radiation group. Histopathological changes of rats organs test liver was well preserved, kidney-the glomeruli, tubules, blood vessel were showed no significant changes, in the stomach-the mucosa, sub mucosa were well, in the spleen-red and white pulp were showed no significant changes, lung-the alveoli was good and in the musclethe skeletal muscle were remain unaltered.
\end{abstract}

Key words: Plants Vitex negundo, Polygonum hydropiper, toxic effect, radiation and rat.

*Author for Corresponding: <mollyharun980@gmail.com>

(02021 Zoological Society of Bangladesh DOI: https://doi.org/10.3329/bjz.v49i1.53688 


\section{INTRODUCTION}

Preservation and processing invariably bring about some changes (most of them are irreversible) in the intrinsic characteristics of the fish. It is a fact that consumers always prefer fresh to preserved fish. The lack of preference for preserved or processed fish is attributed to some extent, due to the changes in the appearance, color, texture, taste and flavor accompanying the processing involved. The severity as well as the irreversibility of the changes will depend on the type of the preservation/processing technique the fish has been subjected to. The developments in fish processing technology over the years have been oriented towards presentation of preserved/processed products with characteristics closely resembling to those of the fresh fish. From the traditional methods of drying, salting etc, the technology of preservation has advanced to canning, freezing and several others of which transportation of fish being the latest (Balachandran, 2001).

According to Balachandran (2001) dried and drying fish are susceptible to many types of spoilage, which can affect the fish qualities and shelf life. Damages due to flies and insects are very significant in open drying under the sun. These are, to a great extent, controlled in mechanical drying, but the postprocess infection as well as damages take place during storage are of equal importance in either type of drying. Most of these can be controlled by adopting hygienic practices in the production side as also maintaining appropriate storage atmosphere.

Biological control methods are harmless and leaves no harmful residue on the stored food commodities. Plants are rich source of compounds having insecticidal activity. Mixing of dried leaves with stored food grains to reduce pest damage is in practice (Raja et al., 1999).

Ghani (1998) observed that a rich source of bio-active compounds are medicinal herbs and serves as an important raw material for the production of such drugs. They constitute a precious natural wealth of a country and contribute a great deal to its health care programmers. Judicious and scientific explosion of this wealth can significantly improve the general health of the people. Being a valuable item of commerce, a country can also earn a good amount of foreign exchange by exporting this natural wealth to other countries. There are many countries in the world which earn a substantial amount of foreign currency by exporting medicinal plants and crude plant drugs. India and Thailand are two glorying examples of such countries in this subcontinent which earn crores of rupees by exporting medicinal plants and their semi-processed products to other countries including Bangladesh. These are still others, such 
as China, India and Pakistan, which utilize their own medicinal plants for local manufacture of both medicines and pharmaceutical products. The export of medicinal plants and spices from Thailand some years ago amounted to 14 million US \$. Obviously exported from India and others tropical countries would be much more than that.

Exception of these specially formulated insecticides, there are several traditional/natural insecticides that are used in various parts of the world to control insects during drying. For example, lime juice and ground chilies are used to control blowflies during sun drying in the Gambia, and the use of pepper has been reported from India, Mali and Nigeria. Sand is sometimes used in the Malawi to control blowflies to protect fresh fish. In Mali, traditional treatments include the dried leaves of a savanna shurb called Boscia senegalensis which is also used in medicine (Clucas and Ward, 1996).

Proctor (1972) obtained that successful methods of controlling insect, pests, micro-organism and weight losses of drying and dried fish have been developed but their vast uses is not far from widespread. The main difficulty is that the greater part of the fish industry in tropical countries is conducted by small traders under relatively primitive conditions, often in remote places. The presents formidable problem of extension of new techniques in such circumstance are the lack of trained personnel to pass on information and the reluctance of many people to adopt new ideas.

Many botanical products having antioxidant, antiviral, antifungal, antibacterial and anticancer application include compounds that undergo hydrolysis and electron transfer (redox) reactions. Phonetic compounds are commonly bound with sugar as glycosides in plants and in starchy and protective parts of the plants. (Baugh and Ignelzi, 2000). Parvin (2003) showed that different extracts of Nerium oleander was less toxic than the different extracts of Randia dometorum to the Heteropneutis fossiles and Channa puctatus fish. Hossain (1976) showed that it is generally agreed that a clear explanation of the safety of irradiated food for consumption must precede any commercial application of the process. It has been demonstrated during the last 25 years that food irradiation technology offers considerable promise, the acceptance of this process by national health authorities has been limited to only a few irradiated foods.

The joint FAO/IAEA/WHO expert committees which reported in 1966 and 1970, have outlined the procedures which should be employed for testing the wholesomeness of irradiated foods. According to Tinsley et al. (1965) ionizing 
radiation is effective in controlling insects in grains and flour at dosages that do not produce qualitative changes in the product. Such a irradiation process offers certain advantages over existing procedures for arthropod control and has been shown to be economically feasible (Cornwell and Bull, 1960, Kraybill and Bruntos, 1960).

The first attempt of present study is to preserve the dried fish individually with extract of medicinal plant and radiation. Nextly to fed the preserved dried fish to the group of rats. Second attempt is to take rats body weight data and histopathological changes test.

\section{MATERIAL AND METHODS}

The investigation was carried out in the Zoological garden under the Department Zoology, University of Dhaka and Sir Salimullah Medical College, Dhaka from August 2004 to December 2004. Plant extracts were prepared in the laboratory of Agrochemical and Environmental Research Division, Institute of Food and Radiation Biology (IFRB), Atomic Energy Research Establishment (AERE), Ganakbari, Savar, Dhaka. The experimental plants and rats were collected from the village Nababgonj and Shakta, under Dhaka district. The plants extracts of leaf and bark of Vitex negundo L. ( Bengali name-Nishinda. Family- Verbenaceae) and Polygonum hydropiper L. (Bengali name-Bishkatali, Family-Polygonaceae) were carried out on laboratory 30 young male rats (Genun-Bandicota indica, Order-Rodentia). Six groups of rats were fed on two different kinds of plants extracts, one kinds of radiation dose and untreated control group. These were, One control group : The control rats were fed on normal food, such as dried fish and wheat. Five treated group : Dry fishes treated 4-ml dose of plant extracts in $70 \%$ ethyl alcohol the ratio of $1: 10$ and 4 kGy irradiated dose. These are $V$. negundo leaf treated fish fed group of rats (VL), V. negundo bark treated fish fed group of rats (VB), P. hydropiper leaf treated fish fed group of rats (PL), P. hydropiper bark treated fish fed group of rats $(\mathrm{PB})$ and radiation treated fish fed group of rats (R).

Body weight gain/loss studies: Body weights were measured to the nearest gram at monthly intervals. There was a scheduled for recording weight gain or loss. The data were analysis from the initial and final body weights variation at 30 and 90 days interval.

Histophathological studies: Three male rats from each group were killed and their organs namely, liver, kidney, stomach, lungs, spleen, muscle wer removed. Permanent slides were prepared the micro-technique (Verma, 1983). 


\section{RESULTS AND DISCUSSION}

Body weights of rats were measured to the gram/month at 30 and 90 days intervals. Initially the concentration of rats body weights were found as, C-43 $\mathrm{g} / \mathrm{m}, \mathrm{VL}-44.8 \mathrm{~g} / \mathrm{m}, \mathrm{VB}-44.4 \mathrm{~g} / \mathrm{m}, \mathrm{PL}-46.2 \mathrm{~g} / \mathrm{m}, \mathrm{PB}-47.8 \mathrm{~g} / \mathrm{m}$ and R-47 $\mathrm{kGy}$ After 30 days the weight gain of rats recorded as, C-324.6 g/m, VL-357.2 g/m, VB-362 g/m, PL- $342 \mathrm{~g} / \mathrm{m}, \mathrm{PB}-323.6 \mathrm{~g} / \mathrm{m}$ and R-352 $\mathrm{kGy}$. After 90 days the body weight were C-727.2 g/m, VL- $781.2 \mathrm{~g} / \mathrm{m}$, VB- $795.8 \mathrm{~g} / \mathrm{m}$, PL-780.4 g/m, PB-764.8 g/m and R-789.8 kGy as shown in Table- 1 .

According to Table- 1 the final rat body weight gain at 90 days interval of six groups followed by C-727.2, PB-764.8, PL-780.4, VL-781.2, R-789.8 and VB795.8 gram/month respectively. After 90 days highest mean weight gain of rat achieved was $795.8 \mathrm{~g} / \mathrm{m}$ by VB treated fish fed group.

According to Tables- 2 and 3 the histopathological changes of rats organs observed no significant effects. In different groups of different plant extracts treated and irradiated fish fed group of rats organs were normal. According to Figure 1 to 12, observed the sections of liver were well preserved, kidney- the glomeruli, tubules, blood vessel were showed no significant changes, in the stomach- the mucosa, submucosa were well, spleen- red and white pulp were showed normal, in the lung- the alveoli was good and in the muscle- the skeletal muscle were showed no significant changes and well preserved. The treated groups which used as the control, did showed no histopathological effect.

Table 1. Showing the rats body weight changes at 30 and 90 days interval

\begin{tabular}{|c|c|c|c|c|c|c|c|c|c|}
\hline Rat group & $\begin{array}{l}\text { No of } \\
\text { rats }\end{array}$ & $\begin{array}{l}\text { Serial no of } \\
\text { observation }\end{array}$ & $\begin{array}{c}\text { Initial } \\
\text { Weight } \\
\text { (g/month) }\end{array}$ & $\begin{array}{c}\text { Initial } \\
\text { mean } \\
\text { Weight } \\
\text { (g/month) }\end{array}$ & $\begin{array}{c}\text { After } \\
\text { 30days } \\
\text { weight } \\
\text { (g/month) }\end{array}$ & $\begin{array}{c}\text { After 30days } \\
\text { mean Weight } \\
\text { (g/month) }\end{array}$ & $\begin{array}{c}\text { After } \\
\text { 90days Rate } \\
\text { of gain } \\
\text { (g/month) }\end{array}$ & $\begin{array}{c}\text { After } \\
\text { 90days } \\
\text { mean } \\
\text { Weight (g) }\end{array}$ & $\begin{array}{c}\text { Mortality } \\
\%\end{array}$ \\
\hline & & 1 & 43 & & 345 & & 755 & & \\
\hline $\begin{array}{l}\text { Control fish fed } \\
\text { group of rat } \\
\text { C }\end{array}$ & 5 & $\begin{array}{l}2 \\
3 \\
4\end{array}$ & $\begin{array}{l}48 \\
45 \\
48\end{array}$ & 43 & $\begin{array}{l}310 \\
277 \\
315\end{array}$ & 324.6 & $\begin{array}{l}685 \\
660 \\
678\end{array}$ & 727.2 & Nil \\
\hline & & $\begin{array}{l}5 \\
1\end{array}$ & $\begin{array}{l}38 \\
41\end{array}$ & & $\begin{array}{l}376 \\
335\end{array}$ & & $\begin{array}{l}858 \\
729\end{array}$ & & \\
\hline $\begin{array}{l}V . \text { negundo } \\
\text { leaftreated fish } \\
\text { fed group of rat } \\
\text { VL }\end{array}$ & 5 & $\begin{array}{l}1 \\
2 \\
3 \\
4 \\
5 \\
1\end{array}$ & $\begin{array}{l}41 \\
46 \\
46 \\
42 \\
49 \\
49\end{array}$ & 44.8 & $\begin{array}{l}348 \\
350 \\
353 \\
400 \\
410\end{array}$ & 357.2 & $\begin{array}{l}747 \\
749 \\
776 \\
905 \\
915\end{array}$ & 781.2 & Nil \\
\hline $\begin{array}{l}\text { V. negundo } \\
\text { bark treated } \\
\text { fish fed group } \\
\text { of rat VB }\end{array}$ & 5 & $\begin{array}{l}1 \\
2 \\
3 \\
4 \\
5 \\
1\end{array}$ & $\begin{array}{l}44 \\
42 \\
46 \\
41 \\
47\end{array}$ & 44.4 & $\begin{array}{l}375 \\
350 \\
344 \\
331 \\
320\end{array}$ & 362 & $\begin{array}{l}823 \\
773 \\
743 \\
725 \\
738\end{array}$ & 795.8 & Nil \\
\hline $\begin{array}{l}\text { P. hydropiper } \\
\text { leaf treated fish } \\
\text { fed group of rat } \\
\text { PL }\end{array}$ & 5 & $\begin{array}{l}1 \\
2 \\
3 \\
4 \\
5\end{array}$ & $\begin{array}{l}47 \\
44 \\
42 \\
49 \\
49\end{array}$ & 46.2 & $\begin{array}{l}320 \\
365 \\
305 \\
395 \\
325 \\
\end{array}$ & 342 & $\begin{array}{l}853 \\
670 \\
888 \\
753\end{array}$ & 780.4 & Nil \\
\hline $\begin{array}{l}\text { P. hydropiper } \\
\text { bark treated } \\
\text { fish fed group } \\
\text { of rat PB }\end{array}$ & 5 & $\begin{array}{l}1 \\
2 \\
3 \\
4 \\
5 \\
1\end{array}$ & $\begin{array}{l}44 \\
42 \\
38 \\
47 \\
68 \\
46\end{array}$ & 47.8 & $\begin{array}{l}375 \\
380 \\
296 \\
217 \\
350 \\
408\end{array}$ & 323.6 & $\begin{array}{l}901 \\
862 \\
657 \\
680 \\
749 \\
920\end{array}$ & 764.8 & Nil \\
\hline $\begin{array}{l}\text { Radiation } \\
\text { treated fish fed } \\
\text { group of rat } R\end{array}$ & 5 & $\begin{array}{l}2 \\
3 \\
4 \\
5\end{array}$ & $\begin{array}{l}46 \\
49 \\
46 \\
45\end{array}$ & 47 & $\begin{array}{l}344 \\
345 \\
336 \\
327\end{array}$ & 352 & $\begin{array}{l}753 \\
758 \\
742 \\
776\end{array}$ & 789.8 & Nil \\
\hline
\end{tabular}


According to Scharer (1977) growing male rats were kept on a restricted feed intake. After 13 weeks they reached a final body weight from $250 \mathrm{~g}$ to in comparison $366 \mathrm{~g}$ of their fed controls. The relative weights of the heart, kidneys,

Table 2. Observations of toxicity or injury in different organs of rats

\begin{tabular}{|c|c|c|c|c|c|}
\hline Rats groups & $\begin{array}{l}\text { Group of } \\
\text { Rats }\end{array}$ & $\begin{array}{c}\text { Fish } \\
\text { feeding } \\
\text { animal }\end{array}$ & $\begin{array}{l}\text { No. of } \\
\text { Rats. }\end{array}$ & $\begin{array}{c}\text { Observati } \\
\text { on (after } \\
\text { days) }\end{array}$ & Remark \\
\hline $\begin{array}{l}\text { Control fish fed } \\
\text { group of rat }\end{array}$ & $\mathrm{C}$ & Rat ô & 5 & 90 & $\begin{array}{l}\text { Liver } \square \text { was well preserved. } \\
\text { Kidney } \square \text { glomeruli, tubules, blood, } \\
\text { vessel were showed no significant } \\
\text { changes. } \\
\text { Stomach } \square \text { mucosa, submucosa and } \\
\text { the muscle layer remain normal } \\
\text { Spleen } \square \text { red and white pulp were } \\
\text { showed no significant changes. } \\
\text { Lung } \square \text { alveoli, branchiole and smooth } \\
\text { muscle were showed no significant } \\
\text { changes. } \\
\text { Muscle } \square \text { skeletal muscle remain } \\
\text { unaltered. }\end{array}$ \\
\hline $\begin{array}{l}\text { V. negundo } \\
\text { (leaf) } \\
\text { treated fish fed } \\
\text { group }\end{array}$ & VL & Rat ô & 5 & 90 & As above \\
\hline $\begin{array}{l}\text { V. negundo } \\
\text { (Bark) } \\
\text { treated fish fed } \\
\text { group }\end{array}$ & VB & Rat ô & 5 & 90 & As above \\
\hline $\begin{array}{l}\text { P. hydropiper } \\
\text { (Leaf)treated } \\
\text { fish fed group }\end{array}$ & PL & Rat ot & 5 & 90 & As above \\
\hline $\begin{array}{l}\text { P. hydropiper } \\
\text { (Bark)treated } \\
\text { fish fed group }\end{array}$ & $\mathrm{Pb}$ & Rat ô & 5 & 90 & As above \\
\hline $\begin{array}{l}\text { Radiation } \\
\text { treated fish fed } \\
\text { group }\end{array}$ & $\mathrm{R}$ & Rat ô & 5 & 90 & As above \\
\hline
\end{tabular}

spleen, pituitary and prostate/seminal vesicle were not altered by underfeeding. The relative weights of the brain, adrenals and testes were increased from 30 to $40 \%$ in the feed restricted groups, the thyroid by about $20 \%$. The relative weight of the liver was decreased by about $30 \%$. When growth is markedly reduced in a toxicity experiment alterations of this kind in the organ weight : body weight ratios have to be expected as a physiological response of the organism to decreased feed intake. They must be differentiated from organ weight changes resulting from primary toxic influences of the drug tested.

Milner and Yen (1956) reported that irradiation of wheat at dosages adequate to control insects does not affect the bread-making properties of flour derived from such wheat. This reports on long-term feeding studies of gammairradiation flour using rats as the experimental animal. 
Table 3. Histopathological observation of treated and untreated group of rats

\begin{tabular}{|c|c|c|c|c|c|c|}
\hline \multirow[t]{2}{*}{ Rats group } & \multirow{2}{*}{$\begin{array}{l}\text { Fish fed } \\
\text { group of } \\
\text { rat } \\
\end{array}$} & \multicolumn{5}{|c|}{ Histopathological changes observed } \\
\hline & & Liver & Kidney & Stomach & Spleen & Lung \\
\hline $\begin{array}{l}\text { Control fish fed } \\
\text { group of rat }\end{array}$ & $\mathrm{C}$ & NSPC & NSPC & NSPC & NSPC & NSPC \\
\hline $\begin{array}{l}V . \text { negundo leaf } \\
\text { treated fish fed } \\
\text { group of rat }\end{array}$ & VL & NSPC & NSPC & NSPC & NSPC & NSPC \\
\hline $\begin{array}{l}V . \text { negundo bark } \\
\text { treated fish fed } \\
\text { group of rat } \\
P . \text { hydropiper }\end{array}$ & VB & NSPC & NSPC & NSPC & NSPC & NSPC \\
\hline $\begin{array}{l}\text { leaf treated fish } \\
\text { fed group of rat }\end{array}$ & PL & NSPC & NSPC & NSPC & NSPC & NSPC \\
\hline $\begin{array}{l}\text { P. hydropiper } \\
\text { bark treated fish } \\
\text { fed group of rat }\end{array}$ & PB & NSPC & NSPC & NSPC & NSPC & NSPC \\
\hline $\begin{array}{l}\text { Radiation treated } \\
\text { fish fed group of } \\
\text { rat }\end{array}$ & $\mathrm{R}$ & NSPC & NSPC & NSPC & NSPC & NSPC \\
\hline
\end{tabular}

(Values are mean $\square \mathrm{SD}$ of 5 replication] Note: (NSPC) no significant pathological change)

In young animals, the effect of a drug increases rats body weight and in size which provides a useful estimate of toxicity. In order to evaluate " "quantitative data, such as body weights, collected in toxicologic studies, it is necessary to apply the methods of statistical analysis. For many toxicologic investigations, a satisfactory method would tell first of all whether treatment did have an effect on weight which is statistically significant. After this is determined, it might also be considered whether the effect of treatment was the same throughout the experiment, i.e., were there any unusual treatment effects at intermediate

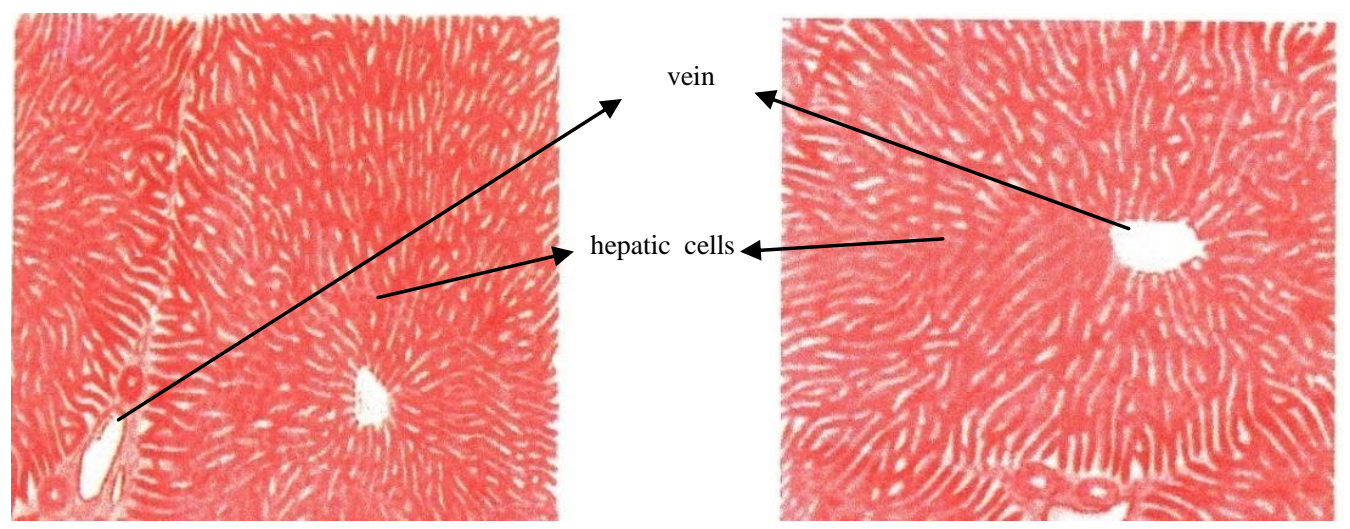

Fig. 1. Photograph showing T.S. of liver of the experimental rats fed on fish treated with irradiated.
Fig. 2. Photograph showing T.S. of liver of the experimental rats fed on fish treated with $V$. negundo bark extract in $70 \%$ ethyl alcohol 


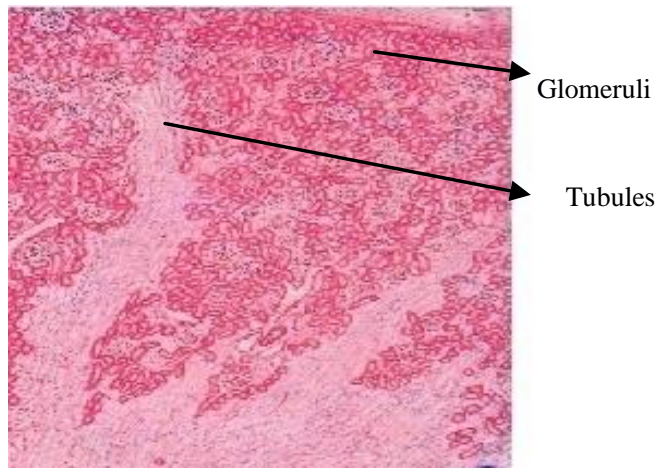

Fig. 3. Photograph showing T.S. of kidney of the experimental rats fed on fish treated with irradiated.

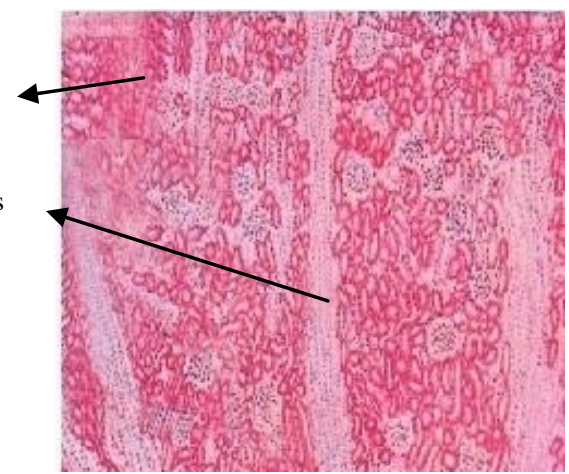

Fig. 4. Photograph showing T.S. of kidney of the experimental rats fed on fish treated with $V$. negundo bark extract in $70 \%$ ethyl alcohol.

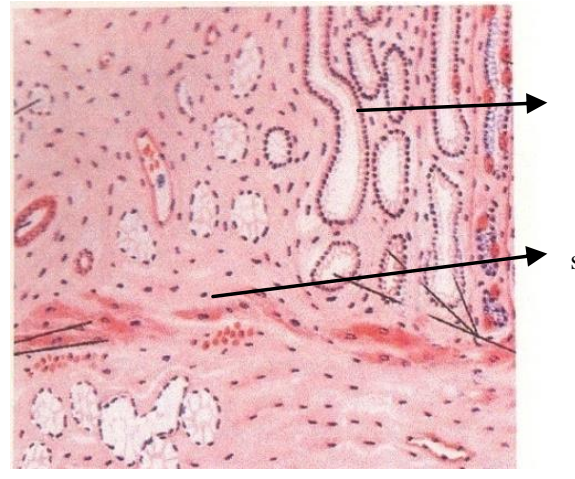

Fig. 5. Photograph showing T.S. of stomach of the experimental rats fed on fish treated with irradiated

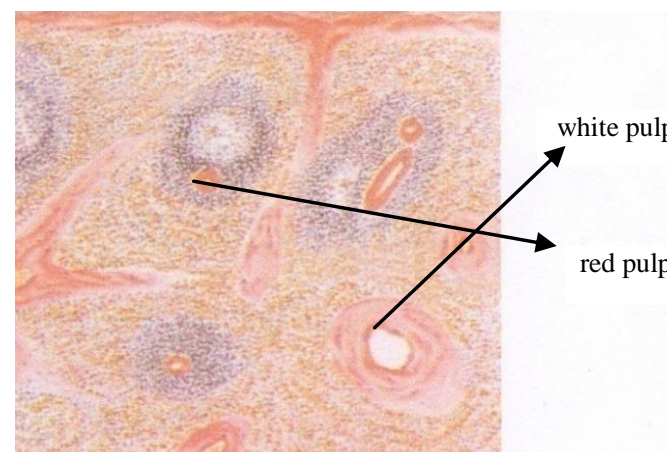

Fig.7. Photograph showing T.S. of spleen of the experimental rats fed on fish treated with irradiated.

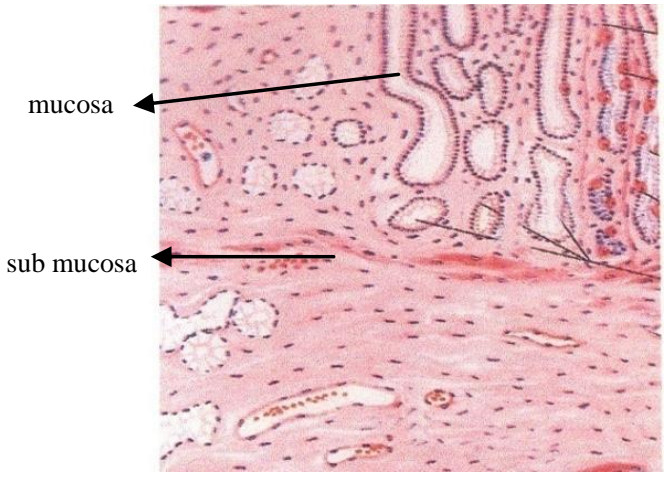

Fig. 6. Photograph showing T.S. of stomach of the experimental rats fed on fish treated with $V$. negundo bark extract in $70 \%$ ethyl alcohol. (Irradiated group)

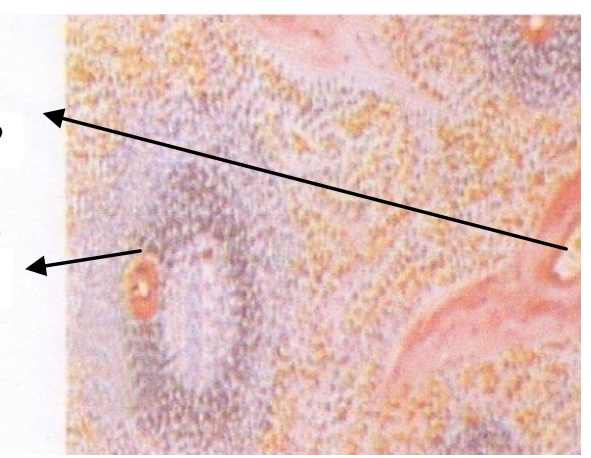

Fig. 8. Photograph showing T.S. of spleen of the experimental rats fed on fish treated with $V$. negundo bark extract in $70 \%$ ethyl alcohol. 


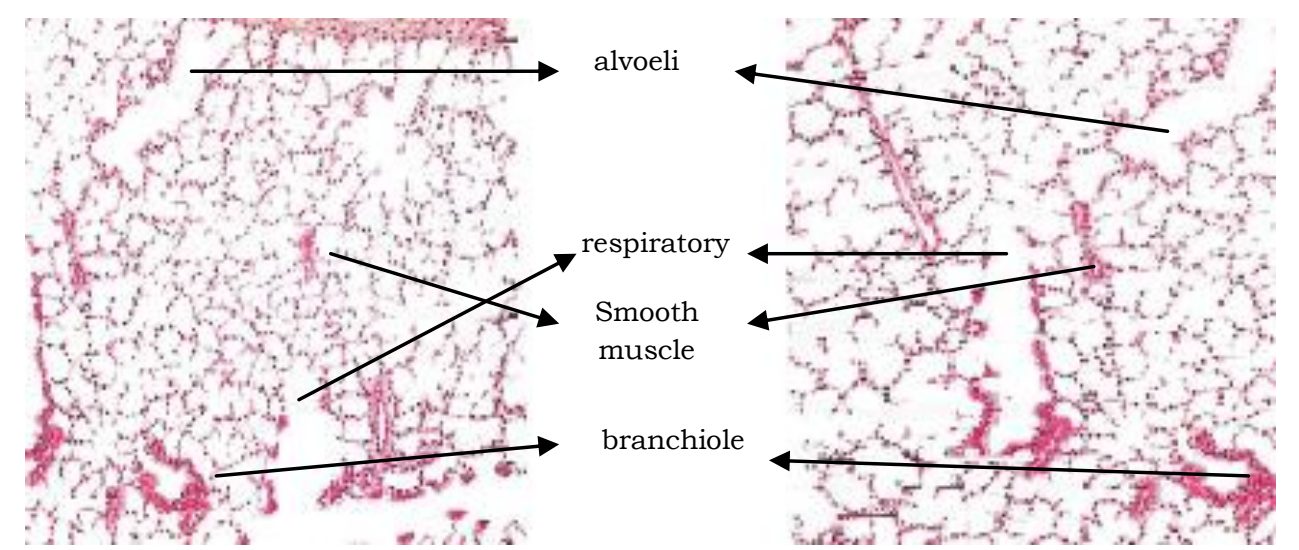

Fig. 9. Photograph showing T.S. of lung of the experimental rats fed on treated with irradiated.

Fig. 10. Photograph showing T.S. of lung of the experimental rats fed on treated with $V$. negundo bark extract in $70 \%$ alcohol solution.

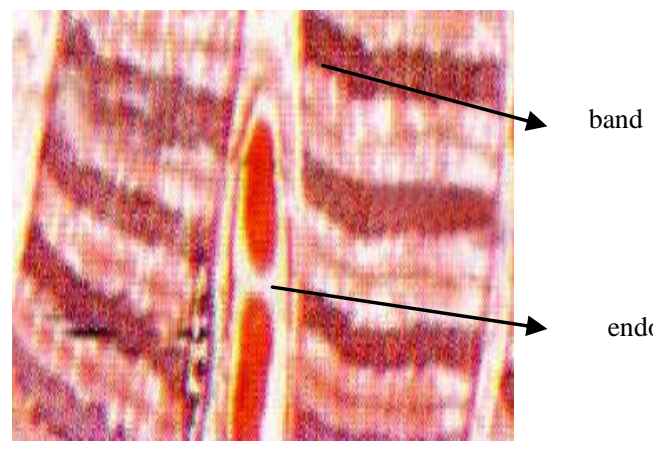

Fig.11. Photograph showing T.S. of muscle of the experimental rat fed on treated with irradiated.

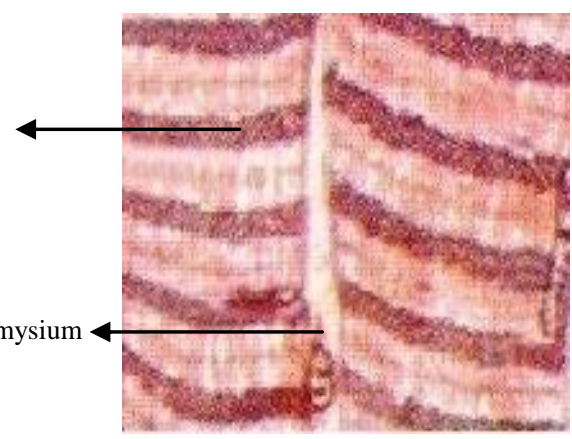

Fig.12. Photograph showing T.S. of muscle of the experimental rat fed on treated with $V$. negundo bark extract in $70 \%$ alcohol solution.

stages. For example, if, at the end of an experiment, the weight gained by the treated rats was less in amount than that of the controls, it might be of interest to know whether the weights were decreased during the whole period of study, which enough to influence the end result. This point is of practical interest when there have been respiratory infections or other episodes of spontaneous disease which might have decreased weight gains during a particular interval (Jackson, 1962).

According to Wish (1938) regarding uniformity of treatment effects by considering the change of growth rate for each animal. This quantity, measurable in units of grams/ months/ month, is analogous to acceleration, and it tells how fast the rate of increase of body weight is changing. By using the analysis of variance on these values it is possible to determine whether treatment exerts a significant effect on the rate of change of growth rate. 


\section{CONCLUSION}

The weight gain by the treated group of rats were best than the control group. The weight were increased during the whole study period . The T.S. sections of the vital organs of rats after treatment such as liver, kidney, spleen, lung and muscle were showed no significant changes and found well preserve. It is noticed that among five kinds of treatments used in present experiment, the 4-ml dose of Vitex negundo bark extracts is the best followed by $4 \mathrm{kGy}$ radiation dose $>$ later by $V$. negundo leaf $>P$. hydropiper leaf $>$ and $P$. hydropiper bark. $V$. negundo bark treated fish fed group of rats body increases in weight. $V$. negundo bark is more suitable significant extract of this experiment. The technology of preservation has determine to controlling plant extract treatment of rats . Dried fish were susceptible to many types of spoilages, plants extracts which can protect this effect of qualities. Successful method of plant extract can significantly improve this method provide good for health of people and earn foreign currency by exporting medicinal plant extract treated dried fish. This will help to our country's economic development. It is also good for researcher for further studies.

\section{LITERATURE CITED}

BALACHANDRAN, K.K.2001. Post-harvest technology of fish and fish products. Daya Publication House, Delhi. 50-75.

BAUGH, S. AND IGNELZI, S. 2000. Hydrolysis and Redox factors affecting analysis of common phenolic marker compounds in Botanical extracts and fished products. Journal of AOAC International. 83(5): 1135-1140.

CLUCAS, I.J. AND WARD, A.R. 1996. Post-harvest Fisheries development: A guide to handling, Preservation, Processing and Quality. Chatham Maritime, Kent ME4 4TB, United Kingdom. 236257.

CORNWELL, P.B. AND BULL, J.O.1960. Insect control by gamma- irradiation: an appraised of the potentialities and problems involved J. Sci. Food. Agr.11:754-768.

GHANI, A. 1998. Medicinal Plants of Bangladesh. Chemical constituents and uses, Asiatic Society of Bangladesh, Dhaka. 30-58.

HOSSAIN, M.M., HUISMAN, J.W. AND DEIHL, J.F. 1976. Mutagenicity studies on irradiated potatoes and chlorogenic acid, micronucleus test in rats. Toxicology. 6: 243-251.

JACKSON, B. 1962. Statistical analysis of body weight data. Toxicology and Applied pharmacology, New York. 432-443.

JOINT FAO/IAEA/WHO Expert Committee on the Technical Basis for Legislation on Irradiated food. 1966. Wid Hlth Org. Techn. Rep. Ser. 316.

JOINT FAO/IAEA/WHO Expert Committee on the Wholesomeness of Irradiated food with special references to Wheat, Potatoes and Onions. 1970. Wid Hlth Org. Techn. Rep. Ser. 451. 
KRAYBILL, H.F. AND BRUNTOS, D.C.1960. Commercialization, technology and economics in radiation processing J.Agr.Food.Chem.8:349-356.

MILNER, M. AND YEN, Y.1956. Treatment of wheat with ionizing radiation, 111. The effect on bread making and related properties, Food. Tech.10:528-531.

PARVIN, S.I. 2003. Study on the pisicidal activity of some indigenous plants in Bangladesh. Ph.D. Thesis, Department of Zoology, DU, Dhaka.226-227.

PROCTOR, D.L. 1972. The control of insect infestation of fish during processing and storage in the tropics. In: Proc. Conf. on handling, processing and marketing of tropical fish. TPI, London. 307-311.

RAJA, N., ALBERT, S. AND IGNACIMUTHU, S. 1999, Effect of solvent residues of Vitex negundo Linn. and Cassia fistula Linn. On pulas beetle, Collosobruchus maculates Fab and its larval parasitoid, Dinarmus vagabundus (Timberlake.) Indian J. of Expt. Bio. 38: 290-292.

SCHARER, K. 1977. The effect of chronic underfeeding on organ weight of rats. Toxicology, New York. 7: 45-56.

TINSLEY, T.J., BONE, J.F. AND BUBL, E.C.1965. The growth, reproduction, longevity and histopathology of rats fad gamma-irradiated flour. Toxicology and applied pharmacology. 7: 71-78.

VERMA, P.S. 1983. A manual of practical Zoology chorodasles. $5^{\text {th }}$ Edition. S. Chand Company Ltd. New Delhi. 91-96.

WISHART, C. 1938. Toxicol Appl. Pharmacol. J. New York. 7. 